\title{
Bacterial feeder Nematodes: Facilitator or competitor for Plant Phosphorus in soil
}

\author{
Palwasha Rehman, Rashid Nazir, Tatheer Alam Naqvi, Arshid Pervez, Usman Irshad* \\ Department of Environmental Sciences COMSATS, University Islamabad (CUI), Abbottabad Campus, Pakistan. \\ *Corresponding author: usmanirshad@cuiatd.edu.pk, usman_agr@yahoo.com
}

\begin{abstract}
Rock phosphate is the main constituent of soil in lower Himalayan region of Pakistan but less accessible to plants. Although a lot of work has been done on the role of phosphate solubilizing bacteria for phosphorus availability from insoluble tricalcium phosphate (TCP), no significant success has yet been achieved at larger scale. The survival and function of introduced $\mathrm{P}$ solubilizing bacteria is directly influenced by their grazers present in soil. We hypothesized that the interactions between P solubilizing bacteria and grazer nematodes are able to improve P liberation from both TCP and bacterial biomass turnover. The hypothesis was tested by growing Pinus roxburghii seedlings in sand medium with or without TCP as a P source. The plants were grown alone or with a TCP solubilizing bacteria and bacterial-feeder nematodes. The test bacteria and the nematodes were isolated originally from pine rhizosphere of P mining zone located in lower Himalaya region of Pakistan. The grazing of bacteria by nematodes enhanced the $\mathrm{P}$ availability in the medium. Although bacteria were abundant in rhizosphere without nematodes they remained less efficient in P liberation compared to that measured in the presence of nematodes. Our data also showed that acidification was not the only reason of $\mathrm{P}$ availability from TCP. Another mechanism was prominent in liberation of the bacterial locked organic phosphorus via phosphatase secretion as a result of nematodes predation. Our results, thus, open a new window towards the success and efficiency of bacterial-based biofertilizer, which mostly fail in the soil.
\end{abstract}

Keywords: Tricalcium P, P mining zone, Phosphatase, Bacteria, Nematodes, Predation.

\section{Introduction}

Phosphorus (P) is gaining much more importance nowadays, not only because of its nutritional essentiality but also because of its depleting natural resource (i.e. rock phosphate). In soils, the main limitation of $\mathrm{P}$ is due to its very reactive nature with cations e.g. calcium and magnesium (in alkaline conditions) and aluminum and iron (in acidic conditions), to form less soluble precipitates consequently leaving it unavailable to plants (Antoun, 2012). Approximately $85-90 \%$ of the applied $\mathrm{P}$ becomes fixed 
and unavailable in soil due to such high reactivity and therefore strongly decreases the actual P availability of added fertilizers or manure (Sharon et al., 2017). Ultimately, the frequent application of $\mathrm{P}$ fertilizers together with its low use-efficiency is increasing the accumulation of residual $\mathrm{P}$ in soils. Phosphate solubilizer microorganisms (PSM), representing about 30\% of the total soil micro flora (Liu et al., 2015), may play a major role in developing a sustainable use of $\mathrm{P}$ resources. Despite the fact of huge proportion of PSM in soil, these microorganisms mobilize enough $\mathrm{P}$ to cover their own needs but not in excess to supply it to plants (Irshad et al., 2011, 2013).

Owen et al, (2015) critically presented that numerous studies have been done and are still continuing regarding the use of soil bacteria and fungi as $\mathrm{P}$ solubilizers. In agricultural ecosystems, more than $40 \%$ of soil cultivable bacteria have the ability to mobilize insoluble and organic P (Jorquera et al., 2008). According to Antoun et al, (2004), most of their Rhizobium and Bradyrhizobium bacterial isolates were able to solubilize di-calcium phosphate while Alikhani et $a l$, (2006) found that $44 \%$ of rhizobia were able to solubilize tricalcium phosphate. Most of the studies about PSB inoculation have been widely conducted under laboratory or controlled glasshouse conditions and showed increased $\mathrm{P}$ solubilization from tricalcium phosphate (Abbasi et al., 2018). Despite the potential role of phosphate solubilizing bacteria in enhancement of $\mathrm{P}$ uptake by plants, not all laboratory and field experiments showed positive results (Gyaneshwar et al., 2002). Two PSB strains belonging to Serratia marcescens and Pseudomonas sp. decreased their efficiency, regarding plant growth, by 49 and $81 \%$ when shifted from glass house to field conditions in maize rhizosphere (Hameeda et al., 2008). The decrease in efficiency of these strains was supposed to link with their survival rate in field as both strains survived only three months in field after application. Similarly, an inoculum of Bacillus megaterium var Phosphoricum was applied successfully in Russia and India, but it did not show the same efficiency in soils of United States (Rodriguez and Fraga, 1999). Gyaneshwar et al, (2002) found no P increase in about $70 \%$ of the experiments related to PSB application in realistic conditions.

The other mechanism governing $\mathrm{P}$ availability in soil is the release of phosphatase enzymes for utilization of organic P compounds by plants and microorganisms. Increased activity of phosphatase occurs in response to $\mathrm{P}$ deficiency as part of $\mathrm{P}$ starvation responses (Richardson and Simpson, 2011). Indeed, phosphatase activity, enhanced in the rhizosphere in response to $\mathrm{P}$ deficiency, has been observed in a wide variety of plant species (Richardson and Simpson, 2011). There is a positive correlation between phosphate-solubilization capacity and phosphatase activity (Irshad and Yergeau, 2018). Relwani et al, (2008) suggested that acid phosphatase plays a major role in P-solubilization, apart from other phosphate-solubilization mechanisms.

Undoubtedly, the success of PSB to sustain in soil ecosystem not only depends on their complexity of interactions with $\mathrm{P}$ and plants but also with soil fauna. Bashan et al, (1995) concluded that when nutrients from the soil were exhausted, the abiotic soil parameters together with the biological interactions in rhizosphere, determined the survival rate of bacteria inoculated to a particular soil. The interaction of inoculated bacteria with their microbial food web partners specifically soil nematodes, is probably one of the crucial factors in determining the effectiveness of $\mathrm{P}$ solubilizers (Becquer et al., 2014). Khan and Joergensen (2009) showed that phosphorus solubilizing bacteria are not sufficient alone as biofertilizer because bacteria assimilate soluble $\mathrm{P}$ as well, making it unavailable to plants. This situation is more pronounced in natural forest ecosystem where diversity of the material 
contributed to a greater efficiency of nutrient cycling without any artificial fertilizer input (Rocha Junior et al., 2018). Similarly, the selected ecosystem representing a high $\mathrm{pH}$ forest soil must possess a mechanism for bacterial organic $\mathrm{P}$ turnover along with $\mathrm{P}$ solubilization via organic acids production.

No studies have yet been reported on bacterial feeding nematodes and their effect on P dynamics. The most relevant study done by Irshad et al, (2012) showed highly significant effect on P release by bacterial grazing from organic sodium phytate source. However, Irshad et al, (2011 \& 2012) showed the importance of bacterial grazer nematodes during plant $\mathrm{N}$ and $\mathrm{P}$ acquisition but all those studies remained limited to simplified agar sterile medium. While recent studies showed the positive effect of bacterial feeder protozoa and nematodes for plant $\mathrm{N}$ nutrition (Zhiyong et al., 2016), no study has ever been reported on P solubilization by these prey-predator interactions under realistic conditions. Also, the contribution of soil fauna to the release of $\mathrm{P}$ from microbial biomass has not yet been well reported by literature. Furthermore, the phosphatase activity by PSB in soil as a result of this complex biological interaction with tricalcium phosphate source is also very scarce in literature.

Therefore, the aim of our study was to evaluate the prey-predator interactions of PSB and nematodes in soil conditions and their ability to mobilize inorganic $P$ from tricalcium phosphorus in the presence of plant (pine) species.

\section{Materials and Methods}

\subsection{Study Area and Soil collection}

The soil samples were collected from the close vicinity of "Gali-Bahn" near Kakul Abbottabad Pakistan. Different sampling points were chosen in between $34.10-34.20^{\circ} \mathrm{N}$ and $73.20-73.30^{\circ} \mathrm{E}$. Gali-Bahn was selected because it belongs to an extensive phosphate mining zone. The area was a pine forest which should therefore represent well established prey-predator underground interactions in lower Himalaya region of Pakistan. Samples were taken up to the depth of 12 inches, with a soil sampler, from the rhizosphere of pine roots. These pine roots belonged to the trees established in patches. Spring season was chosen for sampling and 3-5 different samples were used to make composite sample. The soil represents a high $\mathrm{pH}$ value generally due to abundance of base forming cations in the region.

\subsection{Isolation of Phosphorus solubilizing bacteria (PSB) and their grazer nematodes from soil}

Dilution plate technique was used to isolate the bacteria from 3 composite rhizosphere soil samples. Soil suspensions from $10^{2}-10^{4}$ dilutions were plated on solid pure Pikovskaya's medium (Nautiyal, 1999) with TCP (Tricalcium Phosphate) as the sole $\mathrm{P}$ source. We used this medium because it is specific for the isolation of efficient phosphorus solubilizing bacteria in general (Nautiyal, 1999) by lowering the $\mathrm{pH}$ of the medium. Plates were incubated for $48 \mathrm{~h}$ at $30{ }^{\circ} \mathrm{C}$ and 52 bacterial colonies were able to solubilize TCP. Among them, three efficient PSB strains were selected on the basis of diameter of colonies as well as the measurement of the solubilization hollow. Selected colonies were then maintained on solid Pikovskaya's medium with TCP. Their ability to grow and to liberate free phosphate in liquid Pikovskaya's medium with TCP (same composition as above without Agar) was further studied. The same temperature as of solid media were given in liquid media with an additional agitation of $200 \mathrm{rpm}$ in a growth incubator shaker. Finally, we selected one strain identified as Ochrobactrum anthropic PWB-12 (accession number KU513762.1) for plant inoculation as it displayed 
the best growth, $\mathrm{P}$ release via organic acids and acid phosphatase producing capacities in pure culture (Nazir et al., 2017 \& Hayat et al., 2017). Identification was done (and described in Nazir et al., 2017) with purified bacterial DNA that was used as template for PCR targeting the marker gene i.e. 16S rRNA using primers 27F (5-AGAGTTTGATCCTGGCTCAG-3) and 1492R (5-GGTTACCTTGTTACGACTT-3).

Nematodes were extracted following the Cobb's method (as adopted by (Irshad et al., 2011). Nematodes culturing was made by inoculation of isolated nematodes on solid TSB (Tryptic Soy Broth) medium. Sterilization of nematodes were done according to $\mathrm{Ir}-$ shad et al., 2018 to avoid any bacterial contamination. According to morphological features, isolated nematodes belonged to two bacterial feeder families, Rhabditidae and Cephalobidae. To maintain the nematodes alive, they were collected in sterile water from 3-week old plates and transferred in new plates containing solid TSB and PSB bacteria as sole food source.

\subsection{Preparation of bacterial and nematode inocula and counting}

Bacterial and nematode solution was prepared for inoculation as following. Broth culture of bacterium Ochrobactrum anthropic was centrifuged and the bacterial pellet was re-suspended in sterilized deionized water to ensure that all $\mathrm{P}$ is contained in bacterial biomass. The total numbers of bacteria were counted by hemocytometery. This method allows counting bacteria one by one on a graduated slide under microscope with a magnification of $40 \mathrm{X}$. The number of cells per ml of bacterial solution (counts) was calculated as described elsewhere (http://www.changbioscience.com/cell/hemo.html). Total numbers of nematodes were examined by direct observation under microscope. Dilutions were made and graduated Petri plates were used to count the nematodes one by one under a simple $4 \mathrm{X}$ lens. Nematodes belonging to both families were inoculated at equivalent basis. At plant harvest, bacterial and nematode populations were determined near (rhizosphere soil) and away (bulk soil) from the roots. The numeration was done by taking a known quantity of soil medium, subjected to subsequent dilutions. The nematodes observed at the end of the experiment were morphologically the same as those originally inoculated to plants, suggesting that there were no contamination.

\subsection{Seedling germination and greenhouse experiment}

Seeds of Pinus roxburghii were sterilized with $\mathrm{H}_{2} \mathrm{O}_{2}$ $(30 \%)$ and placed on agar plates having $2 \%$ glucose for germination. Pot filling was performed by mixing sterilized sand with TCP at a rate of $6 \mathrm{~g} \mathrm{Kg}^{-1}$ according to Nazir et al, (2017). Two different sets of pots were filled with $250 \mathrm{~g}$ of sand either mixed with TCP or not. One seedling of pine, three days after germination, was planted per pot. Each pot received $0.5 \mathrm{~mL}$ of bacteria (Ochrobactrum anthropi) and 1 $\mathrm{mL}$ of nematodes suspension representing respectively $5^{*} 10^{7}$ of bacterial cells and approximately 400 nematodes in close vicinity of the root. The pot experiment was conducted with completely randomized design in greenhouse with same treatments (i.e. control (no addition of bacteria and nematodes), control + bacteria, control + bacteria with bacterial feeder nematodes) either in presence or absence of insoluble P source i.e. TCP. Irrigation was applied, to maintain water contents in pots after weighing and visual observation, with $5 \mathrm{~mL}$ of autoclaved salt media $\left(\mathrm{MnSO}_{4}, \mathrm{NH}_{4} \mathrm{NO}_{3}, \mathrm{KCl}, \mathrm{MgSO}_{4}, \mathrm{FeSO}_{4}\right)$ through a sterile syringe when upper $1 \mathrm{~cm}$ sand layer was dried up. Plants were then harvested after two months of growth. Harvesting was done by uprooting the plants in laboratory. Roots and shoots have been separated while determining their fresh 
weights. The plant parts were then dried and grinded for further analysis.

\subsection{Phosphorus analysis}

The water soluble $\mathrm{P}$ in the sand was measured before and after harvesting. Samples were air dried and sieved via $0.5 \mathrm{~mm}$ sieve. A solution of sand and water (1:5) was prepared via shaking for 20 minutes. The solution was filtered through a 0.45 $\mu \mathrm{m}$ filter paper (Whatman, 7404-004). The contents of total $\mathrm{P}$ in roots and shoots were measured after acid digestion of tissues as described by Irshad et al, (2012).

The free orthophosphate concentration was assayed in the soil solution or in mineralized solution using malachite green as done by Irshad et al, (2012).

\subsection{Measurement of medium $\mathrm{pH}$}

Soil samples were thoroughly mixed in water $(1 / 5$, $\mathrm{w} / \mathrm{v})$ for $20 \mathrm{~min}$ before $\mathrm{pH}(\mathrm{w})$ measurement. Standardization of $\mathrm{pH}$ meter was achieved after each treatment by buffers having $\mathrm{pH} 4,7$ and 10 .

\subsection{Measurement of phosphatase activity}

Acid phosphatase activity (phosphomonoesterase) was analyzed by the method as modified by (Irshad and Yergeau, 2018). Briefly, the rhizoplane soil samples were incubated with p-nitrophenyl phosphate (pNPP) as a substrate for enzyme activity for 1 hour. The reaction was terminated with $1 \mathrm{M} \mathrm{NaOH}$ and absorbance was spectrophotometrically determined at wavelength of $400 \mathrm{~nm}$. Controls without soil were processed in parallel to correct for background coloration. Enzyme activities were expressed as mmol $\mathrm{p}-\mathrm{NPP} \mathrm{g}^{-1} \mathrm{~d}$ wt soil $\mathrm{h}^{-1}$.

\subsection{Statistical analysis}

The experiments were performed in completely randomized replicated fashion and the results are reported as mean \pm standard deviation (minimum three number of replicates for each treatment). The differences between means were analyzed by one-way ANOVA followed by Tukey's HSD post-hoc test using Statistica 7.1 (StatSoft Inc., Tulsa, OK, USA). Normality was tested using the Kolmogorov Smirnov test, where necessary.

\section{Results}

\subsection{Phosphorus in roots and shoots with or without} TCP

Phosphorus accumulation in roots and shoots of pine plants as a function of treatments is given in figure $1 \mathrm{a} \& 1 \mathrm{~b}$. In roots, both the addition of TCP and inoculation treatments has shown a highly significant effect $(p<0.01$, Figure 1a). Inoculation treatments have an opposite effect depending on the addition of TCP. Without TCP, root $\mathrm{P}$ accumulation tended to decrease with bacteria $(\mathrm{C}+\mathrm{B})$ and has been decreased significantly with bacteria and nematodes $(\mathrm{C}+\mathrm{B}+$ N) compared to control conditions (C). With TCP, the treatments with bacteria alone $(\mathrm{C}+\mathrm{B})$ and with nematodes $(\mathrm{C}+\mathrm{B}+\mathrm{N})$ have increased respectively by $60 \%$ and $120 \%$ root $\mathrm{P}$ accumulation compared to control conditions (C). Finally, the largest difference of root $P$ accumulation in treatment with TCP compared with treatment without TCP was recorded when pots were inoculated with bacteria and nematodes, with an increase of $630 \%$. Presence and absence of TCP as a P source supplemented with bacteria and bacteria plus nematodes gave opposite results. Shoot $\mathrm{P}$ accumulation was lower in plants grown without TCP than with TCP (Figure 1b). In contrast to root $\mathrm{P}$, the inoculation 
treatments did not modify significantly the amounts of shoot $\mathrm{P}$ of plants not supplied with TCP. When TCP was added to the sand, only the inoculation of bacteria and nematodes $(\mathrm{C}+\mathrm{B}+\mathrm{N})$ significantly increased $(+25 \%)$ shoot $\mathrm{P}$ compared to control treatment. Finally, TCP addition has increased significantly the shoot $\mathrm{P}$ contents compared to the absence of TCP for each inoculation treatment by $60 \%(\mathrm{C}), 53 \%(\mathrm{C}+\mathrm{B})$ and $80 \%(C+B+N)$ (Figure 1b). Shoot P accumulation displayed different results compared to root $\mathrm{P}$ either given TCP or not. Maximum accumulation was recorded in TCP aided treatment with bacterial and nematodes inoculation which was significantly different from control plants $(p<0.01)$.
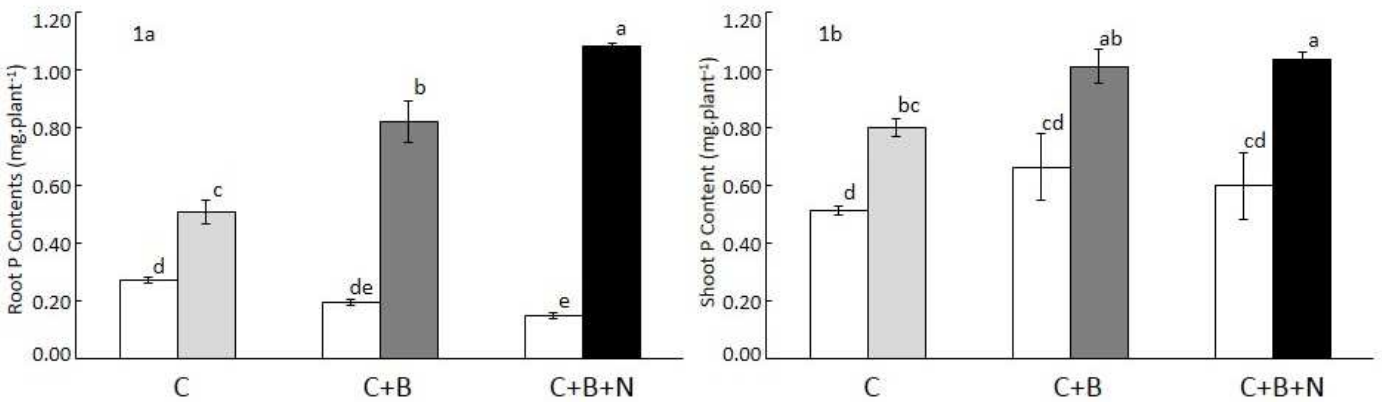

Figure 1. The amount of $\mathrm{P}$ in roots (a) and shoots (b) of Pinus roxburghii grown for 2 months in sand with different treatments i.e. i) control with/without TCP ii) Bacteria inoculated with/without TCP iii) Bacteria and nematodes inoculated with/ without TCP. Bars are means \pm standard error $(\mathrm{n}=3)$. Different letters over the bars indicate significant differences between means at $\mathrm{p}<0.05$ (one-way ANOVA, Tukey's HSD post-hoc test).

\subsection{Net water soluble Phosphorus in sand}

The net available $\mathrm{P}$ of sand was calculated by subtracting the initial amount of water-extractable $\mathrm{P}$ assayed in the sand from the one measured after plant harvesting. Available Pi in sand was higher in treatment inoculated with bacteria and their grazer nematodes compared to un-inoculated or bacteria inoculated treatment (Figure 2). The difference among the treatments was significant $(\mathrm{p}<$ 0.01). The sand samples collected from $\mathrm{C}+\mathrm{B}+\mathrm{N}$ and $\mathrm{C}+\mathrm{B}$ with TCP treatments has showed the greater amount for net water soluble P (21 and $15.7 \mathrm{mg}$ per $250 \mathrm{~g}$ of soil), whereas the minimum amount was found in C with TCP (1.1 mg per 250 $\mathrm{g}$ of soil). 


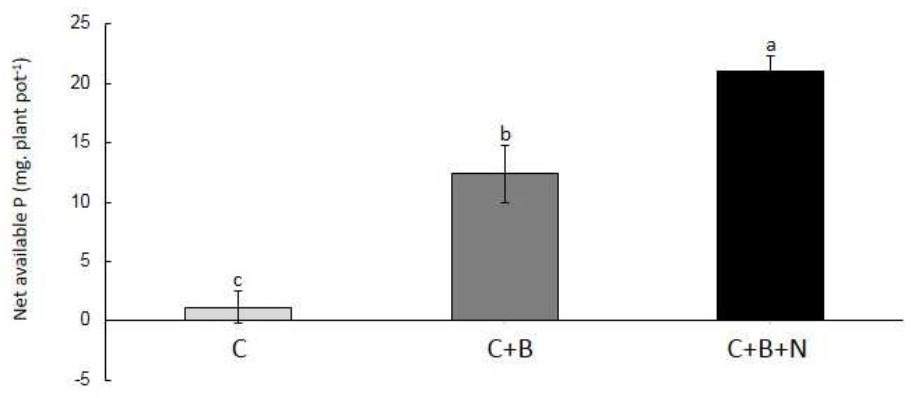

Figure 2. Net free $\mathrm{P}$ concentrations in TCP-amended sand sampled in pots after 2-month growth of Pinus roxburghii. The sand received different treatments i) control ii) inoculated bacteria, iii) bacteria and nematodes inoculation. Bars are means \pm standard error $(n=3)$. Different letters over the bars indicate significant differences between means at $\mathrm{p}<0.05$ (one-way ANOVA, Tukey's HSD post-hoc test).

\subsection{Phosphatase activity and acidification in sand}

Figure 3 represents the comparison of phosphatase activity among treatments with TCP and without TCP (p $<0.01$ ). Higher phosphatase activity has been found in treatment without TCP than in treatment having TCP either inoculated with bacteria or not. Maximum phosphatase activity was found in treatment inoculated with bacteria and nematodes in the absence of TCP. It was significantly different from control and bacterial treatment either having TCP or not in the medium. The lowest phosphatase activity was observed in bacterial inoculated treatment in the presence of TCP compared to all other treatments. Irrespective of TCP addition or not, $\mathrm{C}+\mathrm{B}+\mathrm{N}$ treatments showed significantly enhanced phosphatase activity compared to control treatment. Regardless acidification mechanism no difference has been observed in $\mathrm{pH}$ measured in all different treatments applied (Table 1).

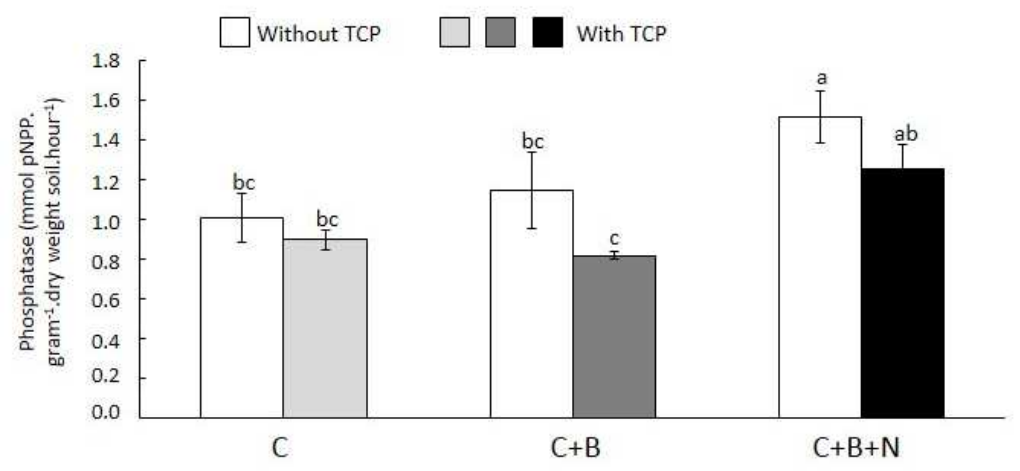

Figure 3. Acid phosphatase activity assayed in sand sampled in pots after 2-month growth of Pinus roxburghii. The sand received different treatments i) control with/without TCP ii) bacteria inoculated with/without TCP iii) bacterial and nematodes inoculated with/ without TCP. Bars are means \pm standard error $(n=3)$. Different letters over the bars indicate significant differences between means at $\mathrm{p}<0.05$ (one-way ANOVA, Tukey's HSD post-hoc test). 
Table 1. $\mathrm{pH}$ of medium measured in sand sampled in pots after 2-month growth of Pinus roxburghii. The sand received two P sources (with TCP or without TCP) and different inoculation treatments: control (c), bacteria inoculated treatment $(\mathrm{c}+\mathrm{b})$ and bacteria and nematodes inoculated treatment $(\mathrm{c}+\mathrm{b}+\mathrm{n})$. Soil samples were extracted with water $(1 / 5, \mathrm{w} / \mathrm{v})$ for $20 \mathrm{~min}$ before $\mathrm{pH}$ measurement. Values given are measurement for each replicated pot $(n=3)$, together with the average.

\begin{tabular}{|c|c|c|}
\hline \multicolumn{2}{|c|}{$\mathrm{pH}$ of Soil samples measured after 60 days of experimentation } \\
\hline Inoculation Treatments & $\begin{array}{c}\text { With } \\
\text { Tricalcium } \\
\text { Phosphorus }\end{array}$ & $\begin{array}{c}\text { Without } \\
\text { Tricalcium } \\
\text { Phosphorus }\end{array}$ \\
\hline Control (c) & $7.89 \pm 0.05$ & $7.75 \pm 0.16$ \\
\hline Control+Bacteria (c+b) & $7.85 \pm 0.08$ & $7.78 \pm 0.15$ \\
\hline Control+Bacteria+Nematodes $(\mathrm{c}+\mathrm{b}+\mathrm{n})$ & $7.90 \pm 0.04$ & $7.90 \pm 0.02$ \\
\hline
\end{tabular}

\subsection{Populations of bacteria and nematodes after} harvesting

After harvesting the pots supplied with TCP, the size of PSB and nematode populations measured either in rhizosphere or bulk soil is given in Figure 4. The results indicate that bacterial populations were not developed in control, during the experiment time, as compared to inoculated one in bacterial alone $(\mathrm{C}+\mathrm{B})$ and bacteria + nematodes $(\mathrm{C}+\mathrm{B}+\mathrm{N})$ treatment, respectively. The p-values calculated for bacterial numbers in rhizosphere and bulk soil either with nematodes were not found significantly different. In addition, higher levels of populations of both preys and predators were found in the rhizosphere than in bulk soil, indicating the positive effect of the plant. Grazing by bacterial feeder nematodes decreased the populations of bacteria compared to treatment without nematodes. Nematodes like bacteria also has been decreased from rhizosphere to bulk soil, however, the population of nematodes tended to be decreased compared to the initial number applied to each pot. 


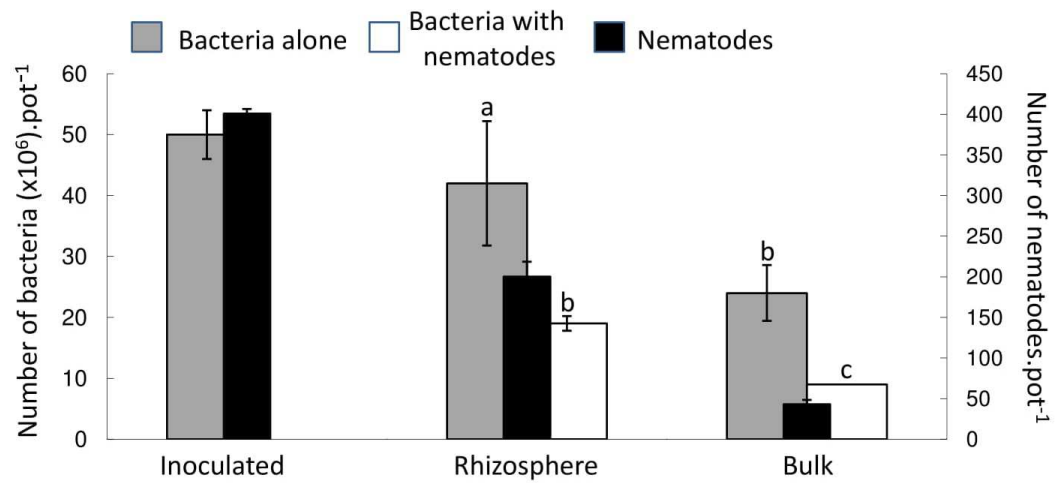

Figure 4. Bacteria and nematodes abundance in start (inoculated), in rhizosphere and bulk soil sampled in pots after 2-month growth of Pinus roxburghii. The plants received TCP as the sole P source. Values are means \pm standard deviation $(n=3)$. Different letters with bacterial numbers in rhizosphere or bulk soil either having nematodes or not indicate significant differences between means at $\mathrm{p}<0.05$ (one-way ANOVA, Tukey's HSD post-hoc test).

\section{Discussion}

\subsection{Phosphorus in roots and shoots with or without TCP}

Relatively higher contents of $\mathrm{P}$ in shoots and roots of pine seedlings were observed in treatments having TCP as a source of inorganic P. In a field trial performed by Kaur and Reddy, 2014 reported that rock phosphate fertilization increased the yield of maize up to $20 \%$ and wheat crop up to $26 \%$ by fertilization along with bacterial inoculation compared with control. Similarly, in our study, bacterial inoculation induced an increasing trend in root and shoots $\mathrm{P}$ contents as compared to control (Figure 1a and 1b). Shah et al, (2001) reported that bacterial inoculation has high phosphate solubilization leading to enhanced nutrient uptake efficiency. Our results are also in line with those reports where Pontoea sp. significantly increased the phosphorus contents of tomato plant (Sharon et al., 2017). The present study has also clearly demonstrated that PSB can play an essential role in the release of $\mathrm{P}$ in soil and increase significantly the plant $\mathrm{P}$ contents in the presence of TCP as P source. Abbasi et al, (2018) found the $\mathrm{P}$ content and P-uptake in the PSBs combined 
treatments, as equivalent to that recorded in plants treated with inorganic P fertilizer, i.e., SSP. Our third treatment having nematodes as bacterial grazer has not increased significantly the $\mathrm{P}$ concentration in shoots but this could be due to the short duration of our experiment (i.e. 2 months) for such hard wood pine species. However, the positive effect of nematodes treatment was noted for root $\mathrm{P}$ accumulation. This could be the result of less competition for solubilized $\mathrm{P}$ uptake between plant roots and bacteria themselves which were actually grazed by predator nematodes. In addition, grazing might release $\mathrm{P}$ assimilated in bacterial biomass and making it more available to plant roots. (Irshad et al., 2011; Irshad et al., 2012: 2018) claimed that the bacteria with their grazer nematodes have increased the availability of $\mathrm{P}$ from organic and inorganic sources in controlled conditions and our results could serve the extension of their findings in soil conditions. Richardson and Simpson, (2011) reported that the grazing activity upon PSB populations could be as efficient as the production of free $\mathrm{P}$ from insoluble mineral $\mathrm{P}$. The treatments without TCP showed no difference or even negative effect of inoculation in case of root $\mathrm{P}$ which might be due to increased competition among plant roots, bacteria and nematodes without any added $\mathrm{P}$ resource.

\subsection{Net water soluble P}

The water soluble P concentrations in sand samples of pine plants were significantly increased in treatment with bacteria alone compared to other treatments but to a lower extent than with bacterial grazer nematodes (Figure 2). Our results, thus, indicate that PSB alone has increased availability of $\mathrm{P}$, but less than in presence of their predators. This could result into bacterial $\mathrm{P}$ assimilation of solubilized $\mathrm{P}$ in their biomass, decreasing $\mathrm{P}$ available to plants as also shown by earlier studies (Irshad et al., 2011). Our results regarding the positive effect of nematodes on $P$ availability are in agreement with those (Irshad et al., 2012; 2018) who also found that the presence of nematodes greatly increased the $\mathrm{P}$ availability to plants in different conditions and bacterial and plant species used. In a bit earlier work, Barsdate et al, (1974) also concluded that bacterial grazed system showed faster P cycle than non-grazed one Richardson, (2001) reported that the most probable reason for $\mathrm{P}$ solubilization without acid production is the release of protons accompanying respiration. As already emphasized by Chen et al, (2007), most of the carbon resources grazed from bacteria by micro-fauna is used for respiration. Therefore, treatment with nematodes probably has higher $\mathrm{CO}_{2}$ concentrations than the other treatments and may increase the acidification in treatment. This would increase the acidity and solubilize insoluble TCP, ultimately enhancing $\mathrm{Pi}$ availability to plants. However, in our case it was not only due to acidification as medium $\mathrm{pH}$ values measured did not change significantly among treatments (Table 1). This might be due to rapid biochemical changes in rhizoplane micro niches formed by roots and microorganisms.

Another possibility to enhance P-availability is the release of bacterial organic $\mathrm{P}$ turnover into the medium via grazing. Park and Ro, (2018) suggested that enhanced microbial activity can increase mineralization of organic $\mathrm{P}$ but relative contribution of exact mechanism remains unclear due to complexity of inorganic and organic $\mathrm{P}$ turnover.

Organic bacterial $\mathrm{P}$ might be mineralized from enzymes released either by nematodes (Chen et al., 2007) or by bacteria (Menezes-Blackburn et al., 2016). In contrast, Gebremikael et al, (2016) reported that water soluble inorganic $\mathrm{P}$ concentration was not significantly different by the presence and absence of different functional groups of soil nematode commu- 
nities. However, he observed a net increase of $23 \%$ in plant's $\mathrm{P}$ availability. Our findings are thus in accordance with the work of many researchers who confirmed that PSB with their grazer nematodes enhance the availability of $\mathrm{P}$ in soil but we showed that it does not only depend upon acidification through respiration. Similar findings were shared by Park and Ro., (2018) by reporting that complete reappraisal of Ca-P based system is needed to solve reported solubility mystery due to lack of knowledge of chemical equilibira between solubility and solid phase.

\subsection{Phosphatase activity}

Our results have revealed that the acid phosphatase activities were measurable in all treatments, with values ranging from 0.8 to $1.4 \mathrm{mmol} \mathrm{pNPP}$ released per $g$ of soil dwt despite the $\mathrm{pH}$ value of the medium was high. These values are of the same order of magnitude as measured in rhizosphere soil of non mycorrhizal Pinus pinaster seedlings grown for 2 months in a sterile chromic cambisol with a low $\mathrm{P}$ content (Van Aarle and Plassard, 2010). Phosphatase activities were greater in soil samples without TCP than with TCP, which is in agreement with the increased secretion of these enzymes by $\mathrm{P}$ starvation (Chen et al., 2007). However, low P availability is probably not the sole factor involved in the regulation of phosphatase activity as the greatest activity was measured in soils with bacteria and nematodes. This increased phosphatase activity, observed in the presence of nematodes, suggests two possible mechanisms i.e., (i) linked with nematodes or (ii) accelerated by bacterial predation. Till now, there is only one report available about extracellular phosphatase activity associated with nematodes (Mao et al., 2005). Chen et al, (2007) reported that the bacterial feeder nematodes significantly enhanced soil respiration rate and soil phosphatase activities.

\subsection{Microbial abundance}

The population of our PSB (Ochrobactrum anthropi) was greater in rhizosphere than in bulk soil due to the growth promoting facets of rhizosphere. Considerably higher concentration of phosphate solubilizing bacteria is commonly found in the rhizosphere in comparison with the non-rhizosphere soil (Liu et al., 2015). The numbers of bacteria found in bulk soil without grazer nematodes were comparable with the ones in rhizosphere soil with nematodes. This result of less bacterial cells found in the presence of nematodes supports another recent data (Trap et al., 2016) as their meta-analysis revealed that bacterivores caused 16$17 \%$ reduction in soil microbial biomass and bacterial abundance. Decrease in bacterial numbers in the presence of nematodes is not in accordance with previous studies done on agar medium in sterilized conditions in the presence of phytate as P source (Irshad et al., 2012). Nematode population decreased during experiment period compared to the inoculum which might be due to fewer bacteria available as food source. This reflects that an abundant bacterial resource is necessary to feed their predators nematodes (Chen et al., 2007). Increased predation could also increase $P$ turnover rate as explained earlier (Irshad et al., 2011) for $\mathrm{N}$ nutrition and distribution of bacteria towards new unexploited resources in rhizosphere.

\section{Conclusions}

Our data showed the role of bacterial grazers in changing $\mathrm{P}$ dynamics in the presence of TCP as a sole P source. A lot of work has been done on bacterial and fungal inoculation based biofertilizers for solubilization of TCP source, despite the fact that their survival and functioning in soil may strongly depend upon grazers (nematodes and protozoa) involved in soil microbial food web as one of the biotic factors. 
The P flux in microbial food web remained positive for plant phosphorus availability in the presence of TCP while during its absence system remained $\mathrm{P}$ deficient. In complex interactions between microorganisms present in rhizosphere, along with respiration other mechanisms like phosphatase secretion at alkaline $\mathrm{pH}$ for bacterial organic $\mathrm{P}$ turn over through nematodes could be a second important mechanism. Our results open a new window and will address the complexities of soil system towards the success and efficiency of bacterial and fungal-based biofertilizer which mostly fail in the field. In future more rhizosphere complexity should be studied to complete other potential missing pieces of the puzzle in the game of $\mathrm{P}$ dynamics in realistic environment.

\section{Acknowledgements}

The research project was supported by a grant from the Higher Education Commission (HEC) of Pakistan via grant number No: 20-3655/ R\&D / HEC / 14 / 400. We thank Dr. Maria Sels and departmental English editing services for linguistic reading and corrections.

\section{References}

Abbasi, M.K., Manzoor, M. 2018. Biosolubilization of phosphorus from rock phosphate and other $\mathrm{P}$ fertilizers in response to phosphate solubilizing bacteria and poultry manure in a silt loam calcareous soil. J. Plant Nut. Soil Sci. 181. 345-356.

Alikhani, H.A., Saleh-Rastin, N., Antoun, H. 2006. Phosphate solubilization of rhizobia native to Iranian soils. Plant Soil. 287, 35-41.

Antoun, H. 2012. Beneficial microorganisms for the sustainable use of phosphates in agriculture. Procedia Engineering. 46, 62-67.
Antoun, H., Beauchamp, C.J., Goussard, N., Chabot, R., Lalande, R. 2004. Potential of Rhizobium and Bradyrhizobium species as plant growth promoting rhizobacteria on non-legumes: Effect on radishes (Raphanus sativus L.). Plant Soil. 204, 57-67.

Bashan, Y., Puente, M.E., Rodriguez-Mendoza, M.N., Toledo, G., Holguin, G., Ferrera-Cerrato, R., Pedrin, S. 1995. Survival of Azospirillum brasilense in the bulk soil and rhizosphere of 23 soil types. Appl. Environ. Microbiol. 61, 1938-1945.

Barsdate, R.J., Prentki, R.T., Fenchel, T. 1974. Phosphorus cycle of model ecosystems: significance for decomposer food chains and effect of bacterial grazers. Oikos. 25, 239-251.

Becquer, A., Trap, J., Irshad, U., Arif, M.A., Plassard, C. 2014. From soil to plant, the outward journey of $\mathrm{P}$ through trophic relationships and ectomycorrhizal association. Front. Plant Sci. 5, 548.

Gebremikael, M.T., Steel, H., Buchan, D., Bert, W., De Neve, S. 2016. Nematodes enhance plant growth and nutrient uptake under $\mathrm{C}$ and $\mathrm{N}$-rich conditions. Scientific Reports. 6, 32862.

Chen, X., Liu, M., Hu, F., Mao, X., Li, H. 2007. Contributions of soil microfauna (protozoa and nematodes) to rhizosphere ecological functions. Acta Ecologica Sinica. 27, 3132-3143.

Gyaneshwar, P., Kumar, N.J., Pareka, L.J., Podle, P.S. 2002. Role of Soil Microorganisms in Improving P Nutrition of Plants. Plant Soil. 245, 83-93. Hameeda, B., Harini, G., Rupela, O.P., Wani, S.P., Reddy, G. 2008. Growth promotion of maize by phosphate solubilizing bacteria isolated from compost and microfauna. Microbiol. Res. 163, 234-242.

Hayat, W., Aman, H., Irshad, U., Azeem, M., Iqbal, A., Nazir, R. 2017. Analysis of ecological attributes of bacterial phosphorus solubilizers, native to pine forests of Lower Himalaya. Appl. Soil Ecol. 112, 51-59. 
Irshad, U., Yergeau, E. 2018. Bacterial Subspecies Variation and Nematode Grazing Change P Dynamics in the Wheat Rhizosphere. Front. Microbiol. 9, 1990

Irshad, U., Villenave, C., Brauman, A., Khan, S.A., Shafiq, S., Plassard, C. 2013. Nitrogen and phosphorus flow stimulated by bacterial grazer nematodes in mycorrhizosphere of Pinus pinaster. Int J. Agric. Biol. 15, 1265-1271.

Irshad, U., Villenave, C., Brauman, A., Plassard, C. 2012. Phosphorus acquisition from phytate depends on efficient bacterial grazing, irrespective of the mycorrhizal status of Pinus pinaster. Plant Soil. 321, 213-233.

Irshad, U., Villenave, C., Brauman, A., Plassard, C. 2011. Grazing by nematodes on rhizosphere bacteria enhances nitrate and phosphorus availability to Pinus pinaster seedlings. Soil Biol. Biochem. 43, 2121-2126.

Jorquera, M.A., Hernández, M.T., Rengel, Z., Marschner, P., Mora, M.D.L.L. 2008. Isolation of culturable phosphobacteria with both phytatemineralization and phosphate-solubilization activity from the rhizosphere of plants grown in a volcanic soil. Biol. Fertil. Soil. 4, 1025-1034.

Kaur, G., Reddy, S.M. 2014. Role of phosphate-solubilizing bacteria in improving the soil fertility and crop productivity in organic farming. Archives of Agron. Soil Sci. 60, 549-564.

Khan, K.S., Joergensen, R.G. 2009. Changes in microbial biomass and $\mathrm{P}$ fractions in biogenic household waste compost amended with inorganic $\mathrm{P}$ fertilizers. Biores. Technol. 100, 303-309.

Liu, Z., Yuncong, L.C., Zhang, S., Fu, Y., Fan, X., Patel, S.J., Zhang, M. 2015. Characterization of phosphate-solubilizing bacteria isolated from calcareous soils. Appl. Soil Ecol. 96, 217-224.
Mao, X., Li, H., Long, M., Hu, F. 2005. Effects of bacteria-feeding nematode at its different density on bacterial number, bacterial activity and soil nitrogen mineralization. Ying Yong Sheng Tai Xue Bao. 16, 1112-6.

Menezes-Blackburn, D., Inostroza, N.G., Gianfreda, L., Greiner, R., Mora, M.L., Jorquera, M.A. 2013. Phytase-producing Bacillus sp. inoculation increases phosphorus availability in cattle manure. J. Soil Sci. Plant Nutr. 16, 200-210.

Nautiyal, C.S. 1999. An efficient microbiological growth medium for screening phosphate solubilizing microorganisms. FEMS Microbiol. Lett. $170,265-270$

Nazir, R., Hayat, W., Rehman, P., Iqbal, A., Irshad, U. 2017. Novel P-Solubilizers from calcium bound phosphate rich pine forest of Lower Himalaya. Geomicrobiol. J. 34, 119-129.

Owen, D., Williams, A.P., Griffith, G.W., Withers, P.J.A. 2015. Use of commercial bio-inoculants to increase agricultural production through improved phosphorus acquisition. Appl. Soil Ecol. $86,41-54$

Park, J.S., Ro, H.M. 2018. Early-stage changes in chemical phosphorus speciation induced by liming deforested soils. J. Soil Sci. Plant Nut. 18, 435-447.

Relwani, L., Krishna, P., Reddy, M.S. 2008. Effect of carbon and nitrogen sources on phosphate solubilization by a wild-type strain and UV-induced mutants of Aspergillus tubingensis. Curr. Microbiol. 57, 401-406.

Richardson, A.E., Simpson, R.J. 2011. Soil microorganisms mediating phosphorus availability update on microbial phosphorus. Plant physiol. 156, 989-96. 
Richardson, A.E. 2001. Prospects for using soil microorganisms to improve the acquisition of phosphorus by plants. Aust. J. Plant Physiol. 8, 897-906.

Rocha Junior, P.R., Ribeiro, P.H., Mesquita, L.F., Andrade, F.V., Mendonça, E.S. 2018. Distribution of $\mathrm{C}$ and inorganic phosphorus fractions in different aggregate sizes under forestry, agroforestry system and pasture. J. Soil Sci. Plant Nut. 18, 361375 .

Rodriguez, H., Fraga, R. 1999. Phosphate solubilizing bacteria and their role in plant growth promotion. Biotechnol. Adv. 17, 319-339.

Shah, P., Kakar, K.M., Zada, K. 2001. Phosphorus use-efficiency of soybean as affected by phosphorus application and inoculation, In W.J Horst (ed.). Plant nutrition-Food Security and Sustain- ability of Agro-ecosystems. Kluwer. Academic Publishers. PP. 670-671 Netherlands.

Sharon, J.A., Hathwaik, L.T., Glenn, G.M., Imam, S.H., Lee C.C. 2017. Isolation of efficient phosphate solubilizing bacteria capable of enhancing tomato plant growth. J. Soil Sci. Plant Nut. 16, 525-536.

Trap, J., Bonkowski, M., Plassard, C., Villenave, C., Blanchart, E. 2016. Ecological importance of soil bacterivores for ecosystem functions. Plant Soil. 398, 1-24.

Zhiyong, Z., Xiaoke, Z., Minggang, X., Shuiqing, Z., Shaomin, H., Wenju, L. 2016. Responses of soil micro-food web to long-term fertilization in a wheatmaize rotation system. Appl. Soil Ecol. 98, 56-64. 